\title{
Article
}

\section{The Perception of the Online Teaching Process during the COVID-19 Pandemic for the Students of the Physical Education and Sports Domain}

\author{
George Danut Mocanu ${ }^{1, \dagger}$, Gabriel Murariu ${ }^{2, *,+} \mathbb{D}$, Daniel Andrei Iordan ${ }^{1,+} \mathbb{C}^{\mathbb{C}}$, Ion Sandu ${ }^{3,4,5, *,+} \mathbb{C}$ \\ and Mihaela Orlanda Antonovici Munteanu $6,+$
}

1 Faculty of Physical Education and Sport, "Dunarea de Jos" University of Galati, 800008 Galati, Romania; George.Mocanu@ugal.ro (G.D.M.); daniel.iordan@ugal.ro (D.A.I.)

2 Faculty of Sciences and Environment, "Dunarea de Jos" University of Galati, 800008 Galati, Romania

3 Academy of Romanian Scientists (AOSR), 54 Splaiul Independentei St., Sect. 5, 050094 Bucharest, Romania

4 Centrul ARHEOINVEST, Departamentul Interdisciplinar Științe, Institutul de Cercetări Interdisciplinare, Universitatea Alexandru Ioan Cuza Iasi, Bld Carol I No. 11, 700506 Iaşi, Romania

5 Forumul Roman de Inventica, Str. Sf. P. Movila 3, L11, III/3, 700089 Iaşi, Romania

6 Facultatea de Geografie și Geologie, Școala Doctorală de Geoștiințe, Universitatea Alexandru Ioan Cuza Iasi, Bld Carol I No. 20A, 700506 Iaşi, Romania; mihaelamunteanu18@yahoo.com

* Correspondence: Gabriel.Murariu@ugal.ro (G.M.); ion.sandu@uaic.ro (I.S.); Tel.: +40-74-012-6940 (G.M.); +40-74-444-31709 (I.S.)

$\dagger$ These authors contributed equally to this paper as senior authors.

Citation: Mocanu, G.D.; Murariu, G.; Iordan, D.A.; Sandu, I.; Munteanu, M.O.A. The Perception of the Online Teaching Process during the COVID-19 Pandemic for the Students of the Physical Education and Sports Domain. Appl. Sci. 2021, 11, 5558 . https://doi.org/10.3390/app11125558

Academic Editor: Antonio Visioli

Received: 6 May 2021

Accepted: 10 June 2021

Published: 16 June 2021

Publisher's Note: MDPI stays neutra with regard to jurisdictional claims in published maps and institutional affiliations.

Copyright: (c) 2021 by the authors. Licensee MDPI, Basel, Switzerland. This article is an open access article distributed under the terms and conditions of the Creative Commons Attribution (CC BY) license (https:// creativecommons.org/licenses/by/ $4.0 /)$.

\begin{abstract}
The context of the COVID-19 pandemic required the implementation of special measures to ensure the continuity and quality of teaching in higher education. The study presented here aims to identify the differences of opinion between the age categories of students in the first year of the Faculty of Physical Education and Sports in Galati, Romania, regarding teaching, learning and assessment activities on online platforms. A total of 147 students divided into three age groups (under 20 years, 20-30 years and over 30 years) filled out a questionnaire composed of items with closed and free answers, structured on four factors (attractiveness, accessibility, motivation and efficiency), after participating in the online teaching and evaluation act during the first semester of the academic year 2020-2021. Multivariate and univariate tests were applied, identifying the influence of the independent age variable on the dependent variables (aspects measured by the items of the questionnaire). Values were obtained at significant thresholds of $\mathrm{F}$ for some of the investigated aspects: boredom induced by online activities, stress value, participation, involvement, motivation and adaptation to the online program, usefulness and quality of teaching process, value of professional training and involvement in disruptive activities. The analysis of the differences between the average scores of the items for the pairs formed by age categories highlighted insignificant values between those under 20 and those aged 20-30, but multiple significant differences between the group of those over 30 and the other two groups. The centralization of free answers by environment (rural and urban) identified the advantages perceived by the students about the online activities (increasing the amount of free time, low financial costs, high accessibility, personal learning pace), the reported disadvantages (technical problems, low concentration, poor socialization) and contradictory proposals to improve activities (continuing online, returning to classical teaching, simplifying the subject, using video materials, involving all students in activities). The paper aims to evaluate the performance of teaching activities performed in the first year of study for the students of physical education and sports, in the context of the COVID-19 pandemic, involving questionnaires validated by the specialty center at the university. The analysis of the results highlighted a series of extremely important aspects that have a role in the future design of activities and courses.
\end{abstract}

Keywords: university education; questionnaires; online teaching; age stages; advantages and disadvantages; pandemic 


\section{Introduction}

Online teaching is currently a basic component of the professional training of teachers, and universities have the duty to invest in their training with new pedagogical methods that are useful in this situation imposed by the pandemic. Creating attractive learning experiences and generating distinct learning environments through digital technologies is a priority of the higher education system, which would facilitate the rapid adaptation to the current challenges of teachers and students with limited experience in e-learning [1].

The challenges of teachers face during online activities focus on the following aspects: optimal operation/use of facilities offered by the work applications, design/development of teaching materials and the assessment, motivating students for higher involvement and using optimal teaching methods [2]. The author of [3] identifies five basic principles for the improvement of the online teaching activities: real support provided by universities and professors to students, with feedback and guidance; efficient provision of information on communication platforms; compatibility and relevance between didactic design and the learning process; high quality involvement to facilitate the depth of the learning act; the existence of backup plans for solving possible unexpected problems in carrying out e-learning activities. The changes made within the education system and the avoidance of dropout also involve the implementation of a hybrid system, which ensures the connection between the classic and the online version, thus reducing the psychological impact for students and teachers [4].

The globalization phenomenon of education and academic mobility programs have been greatly reduced during this period, with the biggest problems being reported in third world countries, where limited resources and poor technical infrastructure generate delays in the process of implementing e-learning. Curricular changes, the transmission of content, the generation of new learning experiences and the development of critical thinking are the challenges of this time interval [5].

The problems signaled by the changes imposed by the pandemic in the field of teaching activities for teachers are complex: anxiety, reduction of direct contacts, change of traditional teaching methods, the need for physical activity and its problems indoors, high workload and stress generated by new working situations [6]. Other authors [7] highlight the problems specific to the academic environment in India, which are the barriers in the qualitative development of training in universities: low budget for the acquisition of highperformance IT technologies, poor training in computer skills, distraction from external factors/family, technical issues, teaching and evaluation problems, negative attitude and lack of motivation.

Both teachers and students identify the advantages and disadvantages of planned online teaching activities [8]. The main positive aspect refers to the protection offered against the virus and the fact that it is the only viable alternative in this context, but the noticed disadvantages are multiple: poor communication, problematic IT equipment and lack of physical interactions. However, the authors believe that this challenge will optimize online education in the future, a statement reinforced by [9], in which the university environment can interpret the pandemic time as an opportunity for innovation and identification of new teaching methods in online distance learning.

Problems in online teaching are reported in Ghana, where students lack the computer and technical skills to study at home, parents cannot help them access and use work platforms and internet access is limited, so the pandemic has affected the quality of training and the learning process, the training of students and teachers being necessary in order to use the platforms efficiently [10].

The effects of the pandemic on university employees and students are reflected primarily through physical inactivity, as a result of the suspension of face-to-face teaching activities and the closure of fitness centers. However, Ref. [11] notes this decline mainly for those with high physical activity; for those with medium and low involvement there is an increase in concerns for physical activity. Instead, López-Valenciano et al. [12] indicates that there is a decrease in involvement in reduced intensity physical activity/walking and very 
intense/vigorous physical activity of students from different countries; the only good thing is that they maintain concerns for maintaining the minimum level of PA (physical activity) during the pandemic, for those who fulfilled it also before the pandemic. Ref. [13] also notes a decrease in involvement in physical effort, but which is compensated by physical activities organized at home. The problems related to physical activities are identified by [14] based on a group of 13,754 Spanish students from 16 universities, finding a decrease in moderate and vigorous physical activity and an increase in time spent performing sedentary activities in over $50 \%$ of cases. However, compensation for these deficiencies through high-intensity activities (HIIT) and through the mind and body, such as yoga type (over $80 \%$ ), is performed by women who are better at managing physical activities and use social networks for this aspect. The number of steps taken by students in the pandemic is higher for men than women, which is noted by the decrease in weekly distances traveled during the pandemic [15].

In the field of physical education, there is the problem of better training the students, with emphasis on online teaching and identifying long-term consequences. If the situation generated by the pandemic is prolonged, the future of this discipline requires the use of digital technologies in practical activities [16]. The authors express their concern about the future of physical education after the end of the pandemic, mentioning as possible solutions the increased percentage of the individual activities to the detriment of group activities, avoiding physical contact and ensuring a greater personal space for each student.

In Romania, the approach of teaching activities was based predominantly on online and hybrid activities from the beginning of the 2020-2021 academic year. This approach has been applied in most university centers. The three adopted scenarios are related to the incidence rate/percentage of infections per thousand inhabitants: the green scenario (with activities carried out face to face/classic), for an incidence rate of less than $0.1 \%$; the yellow scenario, with activities approached in a hybrid system, for an incidence rate of $0.2 \%$; and the red scenario, based exclusively on online education (for an incidence rate of over $0.3 \%$ ). At the level of the Faculty of Physical Education and Sports within the Dunarea de Jos University of Galați, Romania, the hybrid approach was the basic one. The concentration of the theoretical didactic activities was executed online (Monday, Tuesday, Wednesday) and the practical activities were conducted in the open air or in closed spaces with a maximum of 25 students on Thursdays and Fridays. Starting with May 10 or the end of the Easter holiday, as a result of the drastic decrease in the incidence rate, the activity returned $100 \%$ in the classic system.

China's physical education and sports academia rationally combine online and offline/classical activities, but the online version could not fully replace the classic version, due to its multiple disadvantages: difficulties in implementing a regular teaching plan online, poor conditions at home for the performance of physical activities, poor teaching, difficulties in supervising the real involvement of students in lessons, problems in selecting and transmitting information, limited curricular resources, etc. [17]

The perception of safety measures and the impact on the lifestyle of students is varied from one country to another. Some $68 \%$ of Danish students surveyed are complying with government protection measures, correlated with older age, depression and pandemic problems, yet $60 \%$ have no worries about the pandemic [18]. The pandemic has strongly changed the lifestyle of students in Naples, Italy, with men being more affected by quarantine in terms of negative eating behaviors and reduced physical activity [19]. Increased alcohol consumption, physical inactivity, smoking and cannabis use are associated with pandemic depressive symptoms for students at four universities in Germany [20]. The study of [21] on Swiss students indicate that over $25 \%$ of them show depression during the pandemic. 


\section{Materials and Methods}

The purpose of the study aims to identify the perception of students of the Faculty of Physical Education and Sports towards online teaching activities, depending on age and background, by using a questionnaire that measures these opinions.

Working Hypotheses:

Hypothesis 1 (H1). There are significant differences between the average values of the items in the questionnaire, for the three age levels of the students investigated by closed questions.

Hypothesis 2 (H2). The perception on the advantages, shortcomings and options for optimizing the online teaching process differs for the free questions, depending on the background (urban vs. rural).

\subsection{Participants}

The study was based on a group of 147 students from the Faculty of Physical Education and Sports in Galati, Romania. The students are in undergraduate studies in year 1, with the following characteristics related to sex and residence: 84 men and 63 women; 93 students live in the urban areas and 54 in rural areas. The studied group has the following structure by age levels: 76 cases under 20 years, 51 cases between 20 and 30 years and 20 cases over 30 years. All participants were treated in accordance with the Declaration of Helsinki, being informed about the purpose of the study, their involvement being voluntary and respecting the rules on anonymity. The investigation of the research topic was carried out with the consent of the ethics commission of the educational institution. All students in the study completed the questionnaire in full and have accounts on the Microsoft Teams platform, used for teaching activities at Dunărea de Jos University of Galați, Romania.

\subsection{The Organization of the Research}

The construction of the questionnaire was carried out within the Research Center for Human Performance from F.E.F.S. (Faculty of Physical Education and Sport) of Galați. It is structured on 4 separate factors regarding the features of online teaching activities: attractiveness (5 items), accessibility (8 items), motivation (5 items) and efficiency (5 items), totaling 23 items with closed answers. For these items, the Likert scale with 5 steps of intensity was used, and the quantification of the attitudes from the questionnaire in scores is presented in Table 1. Three types of questions with open/free answers were also used. To the items with closed answers, there were 3 additional questions with free answers, focused on identifying the main advantages, shortcomings and proposed solutions to improve the teaching activities carried out online. The questionnaires were sent by e-mail to the study group at the end of the winter session of the academic year 2020-2021 and the beginning of the inter-semester vacation, lasting one week (8-14 February 2021). In this way, the students' opinions could be captured after 14 weeks of online teaching activity, including those related to evaluation. The measured attitudes focus exclusively on the online activities specific to the courses and seminars from semester 1 , with the students being involved in practical activities on small work groups (imposed by the pandemic context) in the case of different sports: athletics, gymnastics and practical applications in winter sports/skating, according to the curriculum of the first year license. There is thus a hybrid teaching system. 
Table 1. Likert scale for questionnaire items.

\begin{tabular}{|c|c|c|c|c|c|c|}
\hline Item & Dependent Variable & 5 & 4 & 3 & 2 & 1 \\
\hline F1.1. & $\begin{array}{l}\text { The attractiveness of } \\
\text { online activities }\end{array}$ & very attractive & attractive & $\begin{array}{l}\text { attractive } \\
\text { environment }\end{array}$ & unattractive & $\begin{array}{c}\text { totally } \\
\text { unattractive }\end{array}$ \\
\hline F1.2. & $\begin{array}{l}\text { Boredom induced by } \\
\text { online activities }\end{array}$ & never & rarely & sometimes & often & always \\
\hline F1.3. & $\begin{array}{l}\text { Socializing in the } \\
\text { online environment }\end{array}$ & very good & high & pretty good & weak & poor \\
\hline F1.4. & $\begin{array}{l}\text { The level of stress in the } \\
\text { online environment }\end{array}$ & non-existent & weak & environment & strong & very strong \\
\hline F1.5. & $\begin{array}{l}\text { Participation in } \\
\text { teaching activities }\end{array}$ & all & the majority & half & occasionally & rarely/not at all \\
\hline F2.1 & $\begin{array}{l}\text { Connecting to the } \\
\text { online platform }\end{array}$ & very affordable & accessible & $\begin{array}{l}\text { moderately } \\
\text { accessible }\end{array}$ & hard to reach & inaccessible \\
\hline F2.2 & $\begin{array}{c}\text { The quality of } \\
\text { online communication }\end{array}$ & very good & good & moderate value & weak & very poor \\
\hline F2.3 & $\begin{array}{l}\text { The difficulty of teaching } \\
\text { activities in the online } \\
\text { environment compared to the } \\
\text { classic ones }\end{array}$ & easy & low difficulty & $\begin{array}{l}\text { medium } \\
\text { difficulty }\end{array}$ & $\begin{array}{l}\text { increased } \\
\text { difficulty }\end{array}$ & $\begin{array}{l}\text { extremely } \\
\text { difficult }\end{array}$ \\
\hline F2.4 & Effects on financial costs & extremely cheap & cheap & $\begin{array}{l}\text { averages as } \\
\text { well as costs }\end{array}$ & costly & very expensive \\
\hline F2.5 & $\begin{array}{l}\text { Quality of conditions at home } \\
\text { in online activities }\end{array}$ & excellent & good & decent level & subpar & $\begin{array}{l}\text { no, they are } \\
\text { inappropriate }\end{array}$ \\
\hline F2.6 & $\begin{array}{l}\text { Adapting to the requirements } \\
\text { of online activities }\end{array}$ & very fast & fast & $\begin{array}{c}\text { average } \\
\text { adjustment }\end{array}$ & difficult/slow & very hard \\
\hline F2.7 & $\begin{array}{l}\text { The need for support from the } \\
\text { institution to access } \\
\text { the platform }\end{array}$ & I succeeded alone & to a small extent & $\begin{array}{l}\text { in moderate } \\
\text { proportion }\end{array}$ & largely & $\begin{array}{l}\text { without help } \\
\text { I couldn't }\end{array}$ \\
\hline F2.8 & $\begin{array}{l}\text { Personal level of IT skills for } \\
\text { working on the platform }\end{array}$ & very good & good level & moderate level & weak level & very weak \\
\hline F3.1. & $\begin{array}{l}\text { Level of motivation to } \\
\text { participate in online activities }\end{array}$ & $\begin{array}{l}\text { extremely } \\
\text { motivated }\end{array}$ & very motivated & $\begin{array}{l}\text { moderately } \\
\text { motivated }\end{array}$ & little motivated & $\begin{array}{c}\text { totally } \\
\text { unmotivated }\end{array}$ \\
\hline F3.2. & $\begin{array}{l}\text { Degree of involvement in } \\
\text { teaching activities }\end{array}$ & very involved & actively involved & $\begin{array}{l}\text { moderately } \\
\text { involved }\end{array}$ & $\begin{array}{l}\text { weakly } \\
\text { involved }\end{array}$ & uninvolved \\
\hline F3.3. & $\begin{array}{l}\text { Concern for the topics } \\
\text { discussed in courses } \\
\text { and seminars }\end{array}$ & very concerned & preoccupied & $\begin{array}{l}\text { partially } \\
\text { concerned }\end{array}$ & a little worried & disinterested \\
\hline F3.4. & $\begin{array}{l}\text { The effect on personal free } \\
\text { time compared to the } \\
\text { classic version }\end{array}$ & a lot of free time & more free time & same free time & less free time & $\begin{array}{l}\text { very little } \\
\text { free time }\end{array}$ \\
\hline F3.5. & $\begin{array}{l}\text { Receiving a sufficient number } \\
\text { of electronic teaching } \\
\text { materials for the study }\end{array}$ & in all subjects & most & $\begin{array}{l}\text { in half of the } \\
\text { subjects }\end{array}$ & $\begin{array}{l}\text { in a few } \\
\text { subjects }\end{array}$ & in no discipline \\
\hline F4.1. & $\begin{array}{l}\text { The usefulness of } \\
\text { online activities }\end{array}$ & very useful & helpful & $\begin{array}{l}\text { average as } \\
\text { a utility }\end{array}$ & not very useful & useless \\
\hline F4.2. & $\begin{array}{l}\text { The quality of the online } \\
\text { teaching act }\end{array}$ & very good & good & medium level & weak & very weak \\
\hline F4.3. & $\begin{array}{l}\text { Perception of the } \\
\text { evaluation act }\end{array}$ & certainly objective & objective & quite objective & weak & very poor \\
\hline F4.4. & $\begin{array}{c}\text { Final level of preparation if } \\
\text { the online vs. } \\
\text { classical teaching }\end{array}$ & very good & better & as & weaker & very weak \\
\hline $\mathrm{F} 4.5$. & $\begin{array}{l}\text { Existence of other concerns } \\
\text { while participating in } \\
\text { online classes }\end{array}$ & never & rare & sometimes & often & always \\
\hline
\end{tabular}




\subsection{The Statistical Analysis of Data}

The statistical processing of the obtained data was performed using the SPSS software version 24. Calculations were performed aiming at determining the Cronbach's alpha indicator at the level of each investigated factor in order to assess the internal consistency [22]; the multivariate analysis MANOVA (F), with the determination of the influence of the independent variable age group on each factor of the questionnaire; the univariate analysis with identification of the influence of the independent variable on each item of the questionnaire [23-26]; the size effect expressed by partial eta squared ( $\eta 2 p)$; Levene's test of equality of error variances; the test of multiple comparison of the averages between the 3 stages of the age groups, with the Bonferroni correction factor; and the percentage value of free answers for subjects from different backgrounds and for the whole study group [27-29]. The confidence interval was set to $95 \%(p<0.05)$. The large volume of resulted data required their selection; the present study analyzes only the influence of the variable age group on the answers with closed responses in the questionnaire, and for the free questions the data were divided by residence: urban vs. rural. The analysis of the variables sex and residence on the answers related to the items of the 4 factors will be sent for publication in another material/article.

\section{Results}

Cronbach's alpha values for all 4 factors of the questionnaire indicate a good fidelity of the features measured by the questionnaire and expressed by students: 0.828 for F1 attractiveness, 0.868 for F2 accessibility, 0.774 for F3 motivation and 0.820 for F4 efficiency.

Table 2 presents the data resulting from the application of the multivariate analysis, identifying the effect of the independent variable/age groups on each factor of the questionnaire, as a dependent variable, composed of several items. The differences between age groups are not significant for the first dependent variables (attractiveness, accessibility and motivation), but are significant for the efficiency variable. Some $5.5 \%$ of the variance of the attractiveness factor is determined/explained by the age groups, $4.9 \%$ for the accessibility and motivation factor, and for the efficiency factor, $6.7 \%$ of the variance is determined by the independent variable; in the latter case, there is an effect of medium size, while in the first three cases there is a low effect.

Table 2. The results of the multivariate/MANEUVER analysis at the level of each factor of the questionnaire.

\begin{tabular}{|c|c|c|c|c|c|c|c|}
\hline Effect/Independent Variable & $\begin{array}{c}\text { Dependent } \\
\text { Variable }\end{array}$ & $\Lambda$ & $\mathbf{F}$ & $\begin{array}{c}\text { Hypothesis } \\
\text { df }\end{array}$ & $\begin{array}{c}\text { Error } \\
\text { df }\end{array}$ & Sig. & $\eta^{2} p$ \\
\hline \multirow{4}{*}{ Age stages } & $\begin{array}{c}\mathrm{F} 1 \\
\text { attractiveness }\end{array}$ & 0.89 & 1.63 & 10.00 & 280.00 & 0.09 & 0.05 \\
\hline & $\begin{array}{c}\text { F2 } \\
\text { accessibility }\end{array}$ & 0.90 & 0.88 & 16.00 & 274.00 & 0.59 & 0.05 \\
\hline & $\begin{array}{c}\text { F3 } \\
\text { motivation }\end{array}$ & 0.90 & 1.44 & 10.00 & 280.00 & 0.16 & 0.05 \\
\hline & $\begin{array}{c}\text { F4 } \\
\text { efficiency }\end{array}$ & 0.87 & 2.03 & 10.00 & 280.00 & 0.03 & 0.06 \\
\hline
\end{tabular}

$\lambda$-Wilk's lambda; F-Fisher test; $\mathrm{df}$ - degrees of freedom; Sig.—level of probability; $\eta^{2}{ }_{\mathrm{p}}$ - partial eta squared.

Table 3 indicates the effect/influence of the independent age group variable on each dependent variable, represented by the separately measured traits, within each item of the questionnaire. Out of the 23 items from the table, only for 10 cases are there significant values of $\mathrm{F}$. 
Table 3. Results of the analysis of univariate/univariate ANOVA at the level of each item of the questionnaire.

\begin{tabular}{|c|c|c|c|c|c|c|c|}
\hline Item & Dependent Variable & $\begin{array}{l}\text { Sum of } \\
\text { Squares }\end{array}$ & df & $\begin{array}{l}\text { Mean } \\
\text { Square }\end{array}$ & $\mathbf{F}$ & Sig. & $\eta^{2} p$ \\
\hline F1.1. & The attractiveness of online activities & 5.80 & 2 & 2.90 & 2.73 & 0.06 & 0.03 \\
\hline F1.2. & Boredom induced by online activities & 7.26 & 2 & 3.62 & 4.29 & 0.01 & 0.05 \\
\hline F1.3. & Socializing in the online environment & 1.26 & 2 & 0.63 & 0.62 & 0.53 & 0.00 \\
\hline F1.4. & The level of stress in the online environment & 7.79 & 2 & 3.89 & 5.05 & 0.00 & 0.06 \\
\hline F1.5. & Participation in teaching activities & 4.84 & 2 & 2.42 & 3.49 & 0.03 & 0.04 \\
\hline F2.1 & Connecting to the online platform & 0.04 & 2 & 0.02 & 0.03 & 0.96 & 0.00 \\
\hline F2.2 & The quality of online communication & 0.91 & 2 & 0.45 & 0.71 & 0.49 & 0.01 \\
\hline F2.3 & $\begin{array}{l}\text { The difficulty of teaching activities in the } \\
\text { online environment compared to the } \\
\text { classic ones }\end{array}$ & 0.17 & 2 & 0.08 & 0.07 & 0.93 & 0.00 \\
\hline F2.4 & Effects on financial costs & 0.15 & 2 & 0.07 & 0.10 & 0.90 & 0.00 \\
\hline F2.5 & $\begin{array}{l}\text { Quality of conditions at home in } \\
\text { online activities }\end{array}$ & 0.00 & 2 & 0.00 & 0.00 & 0.99 & 0.00 \\
\hline F2.6 & $\begin{array}{l}\text { Adapting to the requirements of } \\
\text { online activities }\end{array}$ & 4.75 & 2 & 2.37 & 3.44 & 0.03 & 0.04 \\
\hline F2.7 & $\begin{array}{l}\text { The need for support from the institution to } \\
\text { access the platform }\end{array}$ & 1.94 & 2 & 0.97 & 0.78 & 0.45 & 0.01 \\
\hline F2.8 & $\begin{array}{l}\text { Personal level of IT skills for working on } \\
\text { the platform }\end{array}$ & 0.33 & 2 & 0.16 & 0.22 & 0.79 & 0.00 \\
\hline F3.1. & $\begin{array}{l}\text { Level of motivation to participate in } \\
\text { online activities }\end{array}$ & 6.10 & 2 & 3.05 & 4.04 & 0.02 & 0.05 \\
\hline F3.2. & Degree of involvement in teaching activities & 5.45 & 2 & 2.72 & 3.87 & 0.02 & 0.05 \\
\hline F3.3. & $\begin{array}{l}\text { Concern for the topics discussed at courses } \\
\text { and seminars }\end{array}$ & 3.59 & 2 & 1.79 & 2.85 & 0.01 & 0.03 \\
\hline F3.4. & $\begin{array}{l}\text { The effect on personal free time compared to } \\
\text { the classic version }\end{array}$ & 1.35 & 2 & 0.67 & 0.97 & 0.38 & 0.01 \\
\hline F3.5. & $\begin{array}{l}\text { Receiving a sufficient number of electronic } \\
\text { teaching materials for the study }\end{array}$ & 2.04 & 2 & 1.02 & 1.33 & 0.26 & 0.01 \\
\hline F4.1. & The usefulness of online activities & 7.26 & 2 & 3.63 & 3.96 & 0.02 & 0.05 \\
\hline F4.2. & The quality of the online teaching act & 6.09 & 2 & 3.04 & 5.12 & 0.00 & 0.06 \\
\hline F4.3. & Perception of the evaluation act & 4.67 & 2 & 2.33 & 2.96 & 0.05 & 0.03 \\
\hline $\mathrm{F} 4.4$. & $\begin{array}{l}\text { Final level of preparation if the online vs. } \\
\text { classical teaching }\end{array}$ & 8.89 & 2 & 4.45 & 4.64 & 0.01 & 0.06 \\
\hline F4.5. & $\begin{array}{l}\text { Existence of other concerns while participating } \\
\text { in online classes }\end{array}$ & 9.56 & 2 & 4.78 & 4.39 & 0.01 & 0.05 \\
\hline
\end{tabular}

Statistically significant results are reported for items that measure boredom induced by online activities, for those that measures stress and for those that target the participation in online activities, with values of $\mathrm{F}$ that are related to thresholds of $p<0.05$. Regarding $\eta 2 p, 5.6 \%$ of the variance of the boredom level is attributed to the age groups, $6.6 \%$ for the perceived stress level and only $4.6 \%$ for participating in online activities on the online platform. Adapting to the requirements of online activities also obtains a value of $F$ associated with a significant threshold; in this case, only $4.6 \%$ of the variance of this variable being determined by the age groups, being the only feature of the 8 associated with the accessibility factor, where statistically significant values are obtained. The level of motivation to participate in online teaching activities has also a significant value, with $5.3 \%$ 
of the variance determined by the independent variable, and the degree of involvement in teaching activities is a feature with significant associated value, having $5.1 \%$ of the variance attributed to the influence of age groups. The efficiency factor has the most measured features that obtain significant values of F: the usefulness of online activities, with $5.2 \%$ of the variance determined by the independent variable; the quality of the teaching act in the online version, with $6.6 \%$ of the variance; the estimated level of professional training if online activities would continue vs. the potential level of classical teaching, with $6.1 \%$ of the variance, respectively assuming the existence of other concerns that distract students attention from online activities, with $5.8 \%$ of the variance attributed to age groups. For the rest of the features measured by the other items, insignificant values and low or zero values of size effect $/ \eta 2 p$ were recorded.

Table 4 shows the average scores and standard deviations obtained by each age group (under 20 years, 20-30 years, over 30 years), the differences between the averages of these groups for the 3 resulting pairs and the related significance thresholds. This analysis is extremely useful, as it highlights the differences of opinion between the age groups for each trait measured at the level of each item. It is noticed that the average values are close for the group of those under 20 years and those aged $20-30$ years, in this case the differences being small and statistically insignificant for all 23 items in the table.

Table 4. Multiple comparison on the differences of the averages between the pairs by age groups.

\begin{tabular}{|c|c|c|c|c|c|c|c|c|c|}
\hline Item & Dependent Variable & Lot & Mean \pm SD & $\mathbf{a}-\mathbf{b}$ & Sig. & $a-c$ & Sig. & b-c & Sig. \\
\hline \multirow{3}{*}{ F1.1. } & \multirow{3}{*}{$\begin{array}{l}\text { The attractiveness of } \\
\text { online activities }\end{array}$} & a. $<20$ years & $3.06 \pm 0.95$ & \multirow{3}{*}{-0.01} & \multirow{3}{*}{1.00} & \multirow{3}{*}{-0.58} & \multirow{3}{*}{0.07} & \multirow{3}{*}{-0.57} & \multirow{3}{*}{0.11} \\
\hline & & b. $20-30$ years & $3.07 \pm 1.14$ & & & & & & \\
\hline & & c. $>30$ years & $3.65 \pm 0.98$ & & & & & & \\
\hline \multirow{3}{*}{$\mathrm{F} 1.2$. } & \multirow{3}{*}{$\begin{array}{l}\text { Boredom induced by } \\
\text { online activities }\end{array}$} & a. $<20$ years & $3.25 \pm 0.81$ & \multirow{3}{*}{-0.00} & \multirow{3}{*}{1.00} & \multirow{3}{*}{$-0.65 *$} & \multirow{3}{*}{0.01} & \multirow{3}{*}{$-0.64 *$} & \multirow{3}{*}{0.02} \\
\hline & & b. 20-30 years & $3.25 \pm 1.07$ & & & & & & \\
\hline & & c. $>30$ years & $3.90 \pm 85$ & & & & & & \\
\hline \multirow{3}{*}{ F1.3. } & \multirow{3}{*}{$\begin{array}{l}\text { Socializing in the } \\
\text { online environment }\end{array}$} & a. $<20$ years & $3.36 \pm 1.00$ & \multirow{3}{*}{-0.04} & \multirow{3}{*}{1.00} & \multirow{3}{*}{-0.28} & \multirow{3}{*}{0.80} & \multirow{3}{*}{-0.23} & \multirow{3}{*}{1.00} \\
\hline & & b. 20-30 years & $3.41 \pm 1.09$ & & & & & & \\
\hline & & c. $>30$ years & $3.65 \pm 0.74$ & & & & & & \\
\hline \multirow{3}{*}{ F1.4. } & \multirow{3}{*}{$\begin{array}{l}\text { The level of stress in the } \\
\text { online environment }\end{array}$} & a. $<20$ years & $3.27 \pm 0.75$ & \multirow{3}{*}{0.16} & \multirow{3}{*}{0.96} & \multirow{3}{*}{$-0.57 *$} & \multirow{3}{*}{0.03} & & \\
\hline & & b. 20-30 years & $3.11 \pm 1.03$ & & & & & $-0.73 *$ & 0.00 \\
\hline & & c. $>30$ years & $3.85 \pm 0.87$ & & & & & & \\
\hline & & a. $<20$ years & $3.75 \pm 0.83$ & & & & & & \\
\hline F1.5. & $\begin{array}{l}\text { Participation in } \\
\text { teaching activities }\end{array}$ & b. 20-30 years & $3.82 \pm 0.91$ & -0.07 & 1.00 & $-0.55 *$ & 0.02 & -0.47 & 0.09 \\
\hline & & c. $>30$ years & $4.30 \pm 0.57$ & & & & & & \\
\hline & & a. $<20$ years & $4.05 \pm 0.76$ & & & & & & \\
\hline F2.1 & $\begin{array}{l}\text { Connecting to the } \\
\text { online platform }\end{array}$ & b. 20-30 years & $4.03 \pm 0.93$ & 0.01 & 1.00 & 0.05 & 1.00 & 0.04 & 1.00 \\
\hline & & c. $>30$ years & $4.00 \pm 0.79$ & & & & & & \\
\hline & & a. $<20$ years & $3.71 \pm 0.68$ & & & & & & \\
\hline F2.2 & The quality of online & b. $20-30$ years & $3.74 \pm 0.95$ & -0.03 & 1.00 & -0.24 & 0.70 & -0.20 & 1.00 \\
\hline & & c. $>30$ years & $3.95 \pm 0.75$ & & & & & & \\
\hline & The difficulty of & a. $<20$ years & $3.36 \pm 1.06$ & & & & & & \\
\hline F2.3 & teaching activities in the & b. 20-30 years & $3.29 \pm 1.08$ & 0.07 & 1.00 & 0.02 & 1.00 & -0.05 & 1.00 \\
\hline & online environment & c. $>30$ years & $3.35 \pm 1.22$ & & & & & & \\
\hline & & a. $<20$ years & $3.67 \pm 0.83$ & & & & & & \\
\hline $\mathrm{F} 2.4$ & $\begin{array}{c}\text { Effects on } \\
\text { financial costs }\end{array}$ & b. 20-30 years & $3.64 \pm 0.97$ & 0.02 & 1.00 & -0.08 & 1.00 & -0.10 & 1.00 \\
\hline & & c. $>30$ years & $3.75 \pm 0.71$ & & & & & & \\
\hline
\end{tabular}


Table 4. Cont.

\begin{tabular}{|c|c|c|c|c|c|c|c|c|c|}
\hline Item & Dependent Variable & Lot & Mean \pm SD & $\mathbf{a}-\mathbf{b}$ & Sig. & $a-c$ & Sig. & $\mathbf{b}-\mathbf{c}$ & Sig. \\
\hline \multirow{3}{*}{ F2.5 } & \multirow{3}{*}{$\begin{array}{c}\text { Quality of conditions at } \\
\text { home in } \\
\text { online activities }\end{array}$} & a. $<20$ years & $4.01 \pm 0.88$ & \multirow{3}{*}{0.01} & \multirow{3}{*}{1.00} & \multirow{3}{*}{0.01} & \multirow{3}{*}{1.00} & \multirow{3}{*}{0.00} & \multirow{3}{*}{1.00} \\
\hline & & b. 20-30 years & $4.00 \pm 0.98$ & & & & & & \\
\hline & & c. $>30$ years & $4.00 \pm 0.85$ & & & & & & \\
\hline \multirow{3}{*}{ F2.6 } & \multirow{3}{*}{$\begin{array}{l}\text { Adapting to the } \\
\text { requirements of } \\
\text { online activities }\end{array}$} & a. $<20$ years & $3.50 \pm 0.77$ & \multirow{3}{*}{-0.28} & \multirow{3}{*}{0.18} & \multirow{3}{*}{-0.25} & \multirow{3}{*}{0.20} & \multirow{3}{*}{$0.53 *$} & \multirow{3}{*}{0.04} \\
\hline & & b. 20-30 years & $3.21 \pm 0.87$ & & & & & & \\
\hline & & c. $>30$ years & $3.75 \pm 0.91$ & & & & & & \\
\hline \multirow{3}{*}{ F2.7 } & \multirow{3}{*}{$\begin{array}{l}\text { The need for support } \\
\text { from the institution to } \\
\text { access the platform }\end{array}$} & a. $<20$ years & $3.73 \pm 0.99$ & \multirow{3}{*}{0.22} & \multirow{3}{*}{0.78} & \multirow{3}{*}{0.23} & \multirow{3}{*}{1.00} & \multirow{3}{*}{0.01} & \\
\hline & & b. 20-30 years & $3.51 \pm 1.20$ & & & & & & 1.00 \\
\hline & & c. $>30$ years & $3.50 \pm 1.27$ & & & & & & \\
\hline & Personal level of IT & a. $<20$ years & $3.65 \pm 0.85$ & & & & & & \\
\hline $\mathrm{F} 2.8$ & skills for working on & b. 20-30 years & $3.56 \pm 0.85$ & 0.09 & 1.00 & 0.10 & 1.00 & 0.02 & 1.00 \\
\hline & & c. $>30$ years & $3.55 \pm 0.82$ & & & & & & \\
\hline & Level of motivation to & a. $<20$ years & $3.17 \pm 0.78$ & & & & & & \\
\hline F3.1. & participate in & b. 20-30 years & $3.13 \pm 1.03$ & 0.03 & 1.00 & $-0.57 *$ & 0.02 & $-0.61 *$ & 0.02 \\
\hline & online activities & c. $>30$ years & $3.75 \pm 0.63$ & & & & & & \\
\hline & & a. $<20$ years & $3.26 \pm 0.82$ & & & & & & \\
\hline F3.2. & $\begin{array}{l}\text { Degree of involvement } \\
\text { in teaching activities }\end{array}$ & b. 20-30 years & $3.39 \pm 0.91$ & -0.13 & 1.00 & $-0.58 *$ & 0.01 & -0.45 & 0.12 \\
\hline & & c. $>30$ years & $3.85 \pm 0.67$ & & & & & & \\
\hline & Concern for the tonics & a. $<20$ years & $3.65 \pm 0.72$ & & & & & & \\
\hline F3.3. & discussed at courses & b. 20-30 years & $3.62 \pm 0.97$ & 0.03 & 1.00 & -0.44 & 0.08 & -0.47 & 0.07 \\
\hline & and seminars & c. $>30$ years & $4.10 \pm 0.44$ & & & & & & \\
\hline & The effect on personal & a. $<20$ years & $3.69 \pm 0.92$ & & & & & & \\
\hline F3.4. & free time compared to & b. 20-30 years & $3.50 \pm 0.78$ & 0.19 & 0.65 & -0.05 & 1.00 & -0.24 & 0.83 \\
\hline & the classic version & c. $>30$ years & $3.75 \pm 83$ & & & & & & \\
\hline & Receiving a sufficient & a. $<20$ years & $4.13 \pm 0.69$ & & & & & & \\
\hline F3.5. & $\begin{array}{l}\text { number of electronic } \\
\text { teaching materials for }\end{array}$ & b. 20-30 years & $3.98 \pm 1.17$ & 0.15 & 1.00 & -0.21 & 0.96 & -0.37 & 0.33 \\
\hline & the study & c. $>30$ years & $4.35 \pm 0.48$ & & & & & & \\
\hline & & a. $<20$ years & $3.25 \pm 0.89$ & & & & & & \\
\hline $\mathrm{F} 4.1$ & The usefulness of & b. 20-30 years & $3.03 \pm 1.07$ & 0.21 & 0.67 & -0.50 & 0.11 & $-0.71 *$ & 0.01 \\
\hline & & c. $>30$ years & $3.75 \pm 0.85$ & & & & & & \\
\hline & & a. $<20$ years & $3.93 \pm 0.67$ & & & & & & \\
\hline $\mathrm{F} 4.2$ & $\begin{array}{l}\text { The quality of the } \\
\text { online teaching act }\end{array}$ & b. 20-30 years & $3.80 \pm 0.89$ & 0.13 & 1.00 & $-0.51 *$ & 0.02 & $-0.64 *$ & 0.00 \\
\hline & & c. $>30$ years & $4.45 \pm 0.75$ & & & & & & \\
\hline & & a. $<20$ years & $4.07 \pm 0.81$ & & & & & & \\
\hline $\mathrm{F} 4.3$. & Perception of the & b. 20-30 years & $3.88 \pm 1.03$ & 0.19 & 0.67 & -0.37 & 0.29 & -0.56 & 0.05 \\
\hline & & c. $>30$ years & $4.44 \pm 0.75$ & & & & & & \\
\hline & Final level of & a. $<20$ years & $2.35 \pm 0.90$ & & & & & & \\
\hline $\mathrm{F} 4.4$. & preparation if the online & b. $20-30$ years & $2.45 \pm 1.20$ & -0.09 & 1.00 & $-0.74 *$ & 0.00 & $-0.64 *$ & 0.03 \\
\hline & vs. classical teaching & c. $>30$ years & $3.10 \pm 1.11$ & & & & & & \\
\hline & Existence of other & a. $<20$ years & $3.44 \pm 0.97$ & & & & & & \\
\hline $\mathrm{F} 4.5$. & concerns while & b. 20-30 years & $3.47 \pm 1.22$ & -0.02 & 1.00 & $-0.75 *$ & 0.01 & $-0.73 *$ & 0.02 \\
\hline & online classes & c. $>30$ years & $4.20 \pm 0.76$ & & & & & & \\
\hline
\end{tabular}


There are major differences between the groups of those under 20 years and those over 30 years (eight traits measured), as well as between the averages of those 20-30 years old and those over 30 years (also eight traits). In these cases, students over 30 years of age have average scores of expressed opinions differing as significance thresholds $(p<0.05)$. Even if the online teaching activities are perceived as more attractive for those over 30 years old, the differences compared to the averages of the other two age groups are not significant. Instead, the activities are less boring for them. The average scores of those in the groups under 20 and 20-30 years old indicate higher values of the level of boredom, with significant differences compared to the age group over 30 years $(p=0.02$ and $p=0.027)$. Online socialization has a higher average score for those over 30, but without signaling significant differences compared to the other age groups. The level of stress associated with teaching activities has lower values for those over 30 years, with significant differences in both cases $(p=0.03$ and $p=0.00)$. Participation in classes is also better for students over 30, but a significant difference between the average scores is obtained only compared to the group of those under 20 years old $(p=0.02)$.

Connecting to the work platform is perceived as more problematic for those over 30 , with the lowest average score, but without significant differences. However, they appreciate the quality of online communication, also without significant differences. The scores for assessing the difficulty of online lessons compared to face-to-face teachings are close and with insignificant threshold differences for the three age groups, noting that for those aged 20-30, the perceived difficulty is the highest, and for those under 20 years old, it is the smallest. The financial effects are close as averages for the three groups and with insignificant differences, even if those over 30 have the highest average score, which indicates that for them, the activities are seen as cheaper than the other groups. The appreciation of the quality of the technical and comfort conditions existing at home for conducting online lessons is balanced for the three groups, with very close average values and insignificant differences. A surprising result is the higher average score, which indicates a faster adaptation of those over 30 to the requirements of online teaching, even if the difference is significant only for the comparison with students aged 20-30, who have adapted the hardest $(p=0.048)$. The need for support from the university for accessing the online platform was higher for those over 30 years and students under 20 needed the least help, but without signaling significant differences between the three groups. The perception about their own computer skills has the lowest score for those over 30 and the highest for those under 20, but also without the existence of statistically significant differences.

Students over 30 years of age are the most motivated to participate in teaching activities, with significant average differences compared to the other two groups $(p=0.02$ and $p=0.02$ ), an aspect also strengthened by the higher average score recorded at the actual involvement in activity, but in this case, the significant difference is obtained only by comparison with students under 20 years $(p=0.01)$. Higher average results are obtained by the group of over 30 years regarding concern for the topics discussed at courses and seminars, the perception of increasing leisure time in the case of distance education and satisfaction with the number of online teaching materials posted on the platform in the studied disciplines, but without registering significant differences between the studied groups.

The group of 20-30 years old offered the lowest score for the usefulness of online teaching activities in vocational training, which is perceived with higher values by students over 30 years, with significant differences between these two age groups $(p=0.01)$. The quality of the online teaching is also most appreciated by the group over 30 years old, with significant average differences compared to the other age groups ( $p=0.02$ and $p=0.00)$, the lowest values being recorded by the students aged 20-30 years. The quality and objectivity of online evaluations are also perceived with a higher score by those over 30 years and with a lower score by those 20-30 years old, but in this case, there are no significant differences between the averages of the groups. Students over the age of 30 also believe that the final level of training if the training activities continue online vs. the level of training obtained by using classical teaching methods have the highest score, and those under 20 years old have 
the lowest, with statistically significant differences ( $p=0.00$ and $p=0.03$ ), signaling in this case an overestimation of the formative valences of online education by those over the age of 30, without realizing that limiting or canceling face-to-face practical activities can lead to major shortcomings in the professional training of physical education teachers. The ability to concentrate and not get involved in other activities during classes (browsing the internet, social networks, watching TV, listening to music, watching movies, housework and even activities at work, etc.) is also better for those over 30 years; groups under 20 years and 20-30 years old obtained significantly lower scores, which indicates a greater distraction from classes $(p=0.01$ and $p=0.02)$.

Table 5 summarizes the common answers of all the 147 students surveyed, identifying the number of cases and the percentages for the urban and rural areas and the total value. Figure 1 graphically represents the percentages of the main responses of students in descending order of common answers. The main advantage identified by most of the students is the increase in free time, noting that those in urban areas give a higher percentage value than those in rural areas. The accessibility of online activities regardless of the location and the convenience generated by the comfort of your own home is the second identified advantage, followed by the reduction in financial expenses for transport and rent, with small percentage values in favor of the rural environment, for whom daily commutes were common, especially for the students from the localities neighboring the city of Galati. The fact that other activities are facilitated (including those related to the workplace) is certainly an advantage identified mostly by those in urban areas (19.35\%) vs. rural (5.55\%). Easy online communication follows, although when presenting the problems generated by this type of teaching activity, there are also students who report the communication process as being deficient. Sending and accessing teaching materials in an electronic format is more important for those in rural areas (12.96\%) vs. those in urban areas $(8.6 \%)$. There are also students who mention that there are no identified advantages for teaching online or offer null answers, with rural students offering a higher percentage in this case. The protection offered from the problems generated by the COVID-19 virus is appreciated relatively equally among both environments, and the online version allows a better expression of ideas behind the camera, reducing the states of stress and anxiety that would have manifested in the didactic face to face communication, with higher values offered by rural vs. urban students. Familiarity with IT technologies and the development of their own computer skills are mentioned by a higher percentage of students in urban areas. Other advantages are also mentioned, but by a decreasing number of students, but the most important of these are the high motivation for involvement in the teaching process, the fact that it facilitates their own pace of learning, the high participation of students in teaching activities (an aspect also reported by most teachers in the faculty), financial savings for utilities at the higher education institution, etc.

Table 6 identifies the main shortcomings identified by the students surveyed in relation to online teaching activities, separately by background and as total number, and Figure 2 graphically presents the percentages of the identified common answers, also in descending order.

The main drawbacks reported were the occurrence of technical problems related to IT equipment and poor internet connection, with those in rural areas registering a percentage almost double compared to those in urban areas $(44.44 \%$ vs. $22.58 \%)$, so this aspect can negatively influence the academic performance of that group. Distraction and reduced focus on tasks due to numerous factors (other concerns, noise and disruptive presence of relatives) are reported in relatively equal percentages by both environments. Another identified shortcoming and with balanced percentages for both environments concerns the difficulty of correctly understanding the contents transmitted by teachers. It is then followed by the lack of physical interaction and socialization problems, aspects that affect students in rural areas more than those in urban areas. An obvious imbalance between the environments of origin is the one that signals the exaggerated weight of the theoretical activities in comparison with the practical ones: $17.2 \%$ for urban and $3.7 \%$ for rural. We 
find the same major difference between the percentages of the backgrounds for the time spent in excess on electronic devices, namely telephones, computers and tablets, with those in urban areas registering a triple percentage compared to rural students. Communication problems, the appearance of the microphone phenomenon, unannounced or overlapping interventions of students in the lesson and the delayed connection of some colleagues who make their presence felt by verbal greeting after the beginning of classes bothers more the students in rural areas $(14.81 \%)$ compared to those in urban areas $(8.6 \%)$. The lack of disadvantages or null answers as well as poor knowledge of the teachers and colleagues in their own group or year of study are reported in a higher percentage by the students in urban areas. An issue reported in balanced percentages by both groups and which has been reported by many teachers is that of students who are connected to the platform, but have little or no involvement in teaching activities, with many of them just wanting to register the mandatory attendance of the seminar activities. Boredom is a problem reported in a higher percentage by those in rural areas, with many students declaring that they lack the feeling of belonging to the university environment due to isolation. Other problems reported, but with lower percentage values, relate to the perception that the professional training will suffer, the lack of a strong motivation for involvement in online activities, stress, nervous fatigue and the manifestation of anxiety, excess free time not properly valued, successive teaching activities with short breaks which do not allow students to relax, lack of teaching materials in printed format, etc.

Table 5. Ordering the advantages offered by the online activity based on the source environment.

\begin{tabular}{|c|c|c|c|c|c|c|c|}
\hline \multirow{2}{*}{$\begin{array}{l}\text { Nr. } \\
\text { Crt. }\end{array}$} & \multirow{2}{*}{ Advantages/Expressed Opinion } & \multicolumn{2}{|c|}{ Urban/93 } & \multicolumn{2}{|c|}{ Rural/54 } & \multicolumn{2}{|c|}{ Total/147 } \\
\hline & & Nr. & $(\%)$ & Nr. & $(\%)$ & Nr. & $(\%)$ \\
\hline 1 & We have more free time & 29 & 31.18 & 20 & 37.03 & 49 & 33.33 \\
\hline 2 & Accessibility/We can attend classes at home or other locations & 29 & 31.18 & 17 & 31.48 & 46 & 31.29 \\
\hline 3 & Reduced costs related to commuting and rent money & 25 & 26.88 & 15 & 27.77 & 40 & 27.21 \\
\hline 4 & We can work or do other activities during classes & 18 & 19.35 & 3 & 5.55 & 21 & 14.28 \\
\hline 5 & Better and easier communication at courses and seminars & 9 & 9.67 & 4 & 7.40 & 13 & 8.84 \\
\hline 6 & Existence of teaching materials in electronic format & 8 & 8.60 & 7 & 12.96 & 15 & 10.20 \\
\hline 7 & There are no null advantages/answers & 7 & 7.52 & 5 & 9.25 & 12 & 8.16 \\
\hline 8 & Good protection against COVID-19 & 7 & 7.52 & 4 & 7.40 & 11 & 7.48 \\
\hline 9 & Reduced stress and anxiety, courage in expressing ideas & 4 & 4.30 & 4 & 7.40 & 8 & 5.44 \\
\hline 10 & Using IT technology and better IT skills & 5 & 5.37 & 2 & 3.70 & 7 & 4.76 \\
\hline 11 & Better professional training & 4 & 4.30 & 2 & 3.70 & 6 & 4.08 \\
\hline 12 & Increased motivation to participate & 3 & 3.22 & 2 & 3.70 & 5 & 3.40 \\
\hline 13 & Existence of personal learning rhythm & 4 & 4.30 & 1 & 1.85 & 5 & 3.40 \\
\hline 14 & It is easier to listen than to write in class & 2 & 2.15 & 1 & 1.85 & 3 & 2.04 \\
\hline 15 & The security offered by the platform and its options & 1 & 1.07 & 0 & - & 1 & 0.68 \\
\hline 16 & Watch HD videos at home & 1 & 1.07 & 0 & - & 1 & 0.68 \\
\hline 17 & Large number of students present in class & 1 & 1.07 & 0 & - & 1 & 0.68 \\
\hline 18 & Savings with college utilities & 0 & - & 1 & 1.85 & 1 & 0.68 \\
\hline 19 & Better punctuality & 0 & - & 1 & 1.85 & 1 & 0.68 \\
\hline 20 & It is easier to work in teams for essays & 0 & - & 1 & 1.85 & 1 & 0.68 \\
\hline
\end{tabular}




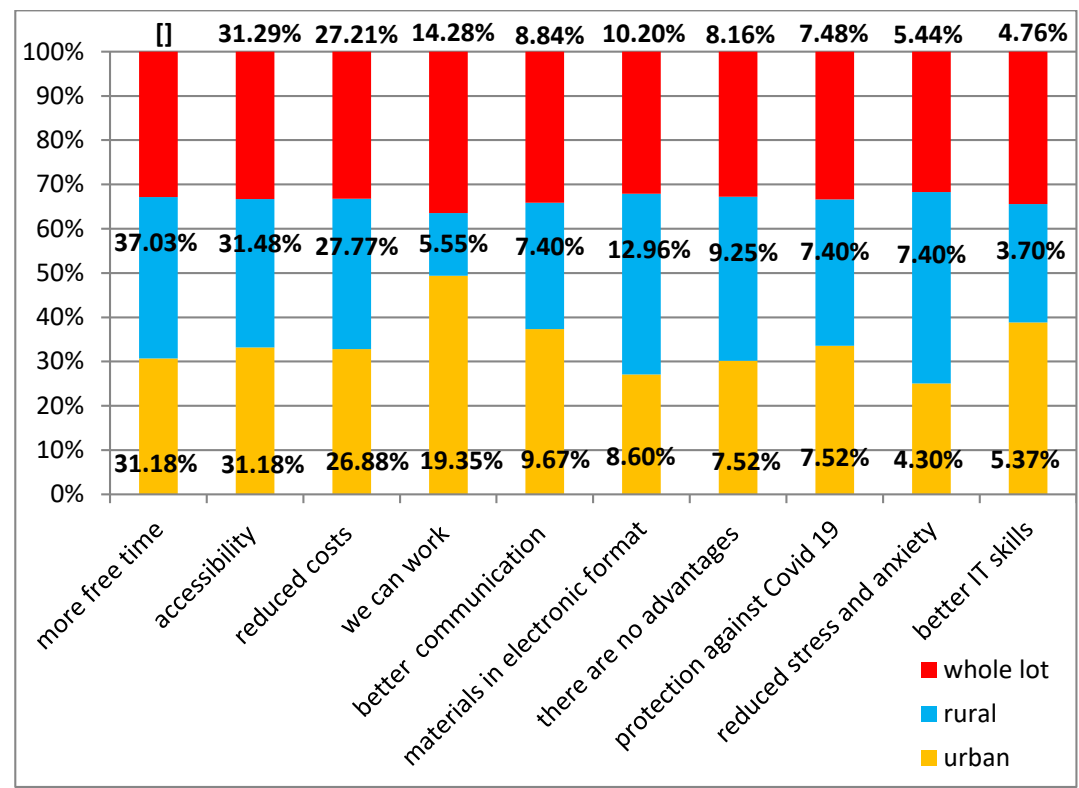

Figure 1. Graphical representation of the main advantages offered by online activities.

Table 6. Ordering the problems generated by the online activity based on the origin environment.

\begin{tabular}{|c|c|c|c|c|c|c|c|}
\hline \multirow{2}{*}{$\begin{array}{l}\text { Nr. } \\
\text { Crt. }\end{array}$} & \multirow{2}{*}{ Disadvantages/Expressed Opinion } & \multicolumn{2}{|c|}{ Urban/93 } & \multicolumn{2}{|c|}{ Rural/54 } & \multicolumn{2}{|c|}{ Total/147 } \\
\hline & & Nr. & $(\%)$ & Nr. & $(\%)$ & Nr. & $(\%)$ \\
\hline 1 & Deficiencies in internet connection and technical problems & 21 & 22.58 & 24 & 44.44 & 45 & 30.61 \\
\hline 2 & Reduced focus on online activities & 19 & 20.43 & 11 & 20.37 & 30 & 20.40 \\
\hline 3 & I do not understand very well the ideas/information transmitted & 18 & 19.35 & 11 & 20.37 & 29 & 19.72 \\
\hline 4 & Lack of physical interaction & 17 & 18.27 & 7 & 12.96 & 24 & 16.32 \\
\hline 5 & Poor socialization & 16 & 17.20 & 8 & 14.81 & 24 & 16.32 \\
\hline 6 & Too much theory, too few practical activities & 16 & 17.20 & 2 & 3.70 & 18 & 12.24 \\
\hline 7 & Excess time spent on computer/phone & 10 & 10.75 & 2 & 3.70 & 12 & 8.16 \\
\hline 8 & Difficult communication, microphone, simultaneous speech & 8 & 8.60 & 8 & 14.81 & 16 & 10.88 \\
\hline 9 & There are no disadvantages/zero answers & 8 & 8.60 & 3 & 5.55 & 11 & 7.48 \\
\hline 10 & We don't know our teachers and all our colleagues well & 6 & 6.45 & 2 & 3.70 & 8 & 5.44 \\
\hline 11 & Colleagues who connect but do not participate, do not respond & 5 & 5.37 & 3 & 5.55 & 8 & 5.44 \\
\hline 12 & I'm bored, I don't feel like I'm in college & 4 & 4.30 & 5 & 9.25 & 9 & 6.12 \\
\hline 13 & Professional training will be poor & 4 & 4.30 & 4 & 7.40 & 8 & 5.44 \\
\hline 14 & Poor motivation to learn & 3 & 3.22 & 3 & 5.55 & 6 & 4.08 \\
\hline 15 & High fatigue, stress and anxiety & 2 & 2.15 & 3 & 5.55 & 5 & 3.40 \\
\hline 16 & I can't always connect from work & 2 & 2.15 & 0 & - & 2 & 1.36 \\
\hline 17 & We have too much free time & 1 & 1.07 & 1 & 1.85 & 2 & 1.36 \\
\hline 18 & Too short breaks between teaching activities & 1 & 1.07 & 1 & 1.85 & 2 & 1.36 \\
\hline 19 & Teaching is sometimes mechanical & 1 & 1.07 & 0 & - & 1 & 0.68 \\
\hline 20 & Drawing and graphics options cannot be used & 1 & 1.07 & 0 & - & 1 & 0.68 \\
\hline 21 & Teaching materials in print/physical format are missing & 1 & 1.07 & 0 & - & 1 & 0.68 \\
\hline 22 & Limited objectivity in some cases & 0 & - & 1 & 1.85 & 1 & 0.68 \\
\hline 23 & Activities such as the prom cannot be organized & 0 & - & 1 & 1.85 & 1 & 0.68 \\
\hline
\end{tabular}




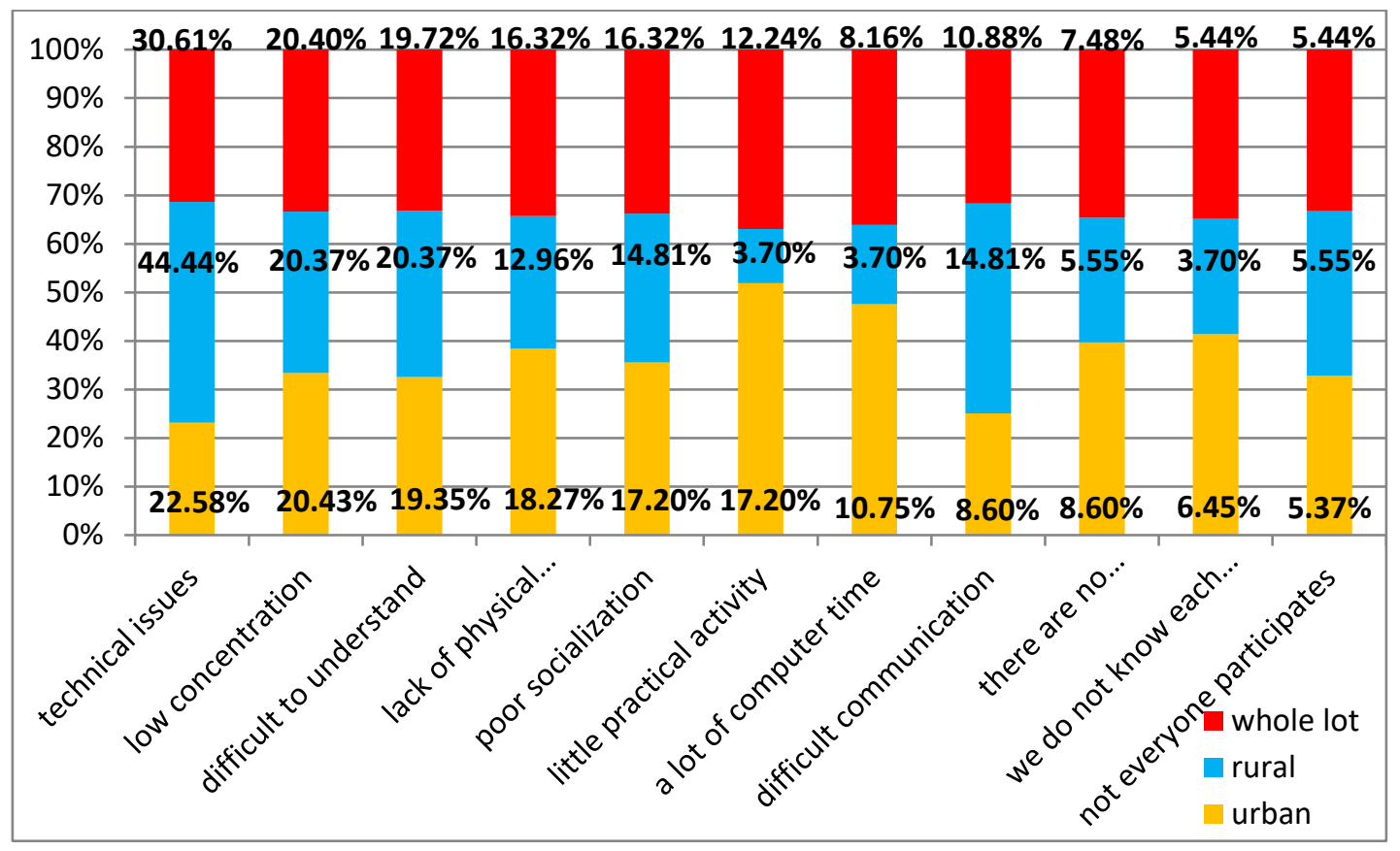

Figure 2. Graphical representation of the main disadvantages encountered in online activities.

Table 7 shows the main proposals given by the students and whose role it is to regulate and improve the teaching, learning and assessment process on online platforms and Figure 3 shows the percentages obtained by residence and total for the main ideas offered by them. Unlike the signaling of the positive aspects and the deficiencies in online education, in this case the registered proposals are much more numerous, but with lower percentage values, this aspect identifying a heterogeneous vision on the ways of optimizing the teaching process.

Surprisingly, most students have nothing to propose or offer null answers, balanced for urban (37.63\%) vs. rural (37.03\%), but there is in many of the remaining situations a real avalanche of proposed ideas. A big question mark is the second proposal as a share, where students from urban areas $(10.75 \%$ ) and those from rural areas (only $1.85 \%$ ) want to continue the teaching process online, being very satisfied with the results. The overall percentage of the whole group for this proposal (7.48\%) is higher than the global percentage concerning the desire to return as soon as possible to classic teaching, which is only $5.44 \%$, indicating a good adaptation to the requirements of online teaching, but must be correlated with the advantages related to the possibility to work without changing the work schedule or the need for agreements in order to participate in classes. The desire to return to classical teaching is higher for those in rural areas than for students in urban areas $(7.4 \%$ vs. $4.3 \%$ ). Another proposal refers to the use of live demonstrations and video materials that facilitate the understanding of the specialized information provided and compensate for the restriction of practical activities; those in rural areas have a higher percentage in this regard. The need for effective participation with direct personal interventions for all students in order to avoid the monopolization of discussions by the teacher and a small circle of students is another aspect signaled in balanced percentages by the two groups. Another proposal aims to improve the access to the platform and to diversify its functions, with similar percentages for the two environments. Other proposals that are extremely numerous, but obtain low percentage scores, include simplifying the taught subject in order to help students understand and assimilate the basic ideas, approaching the topics and chapters taught through a series of fun and attractive activities meant to increase participants' interest, facilitating more free discussions to encourage the expression of one's own ideas in less scientific terms, shortening the duration of teaching activities and increase the breaks between them, limiting reference papers for different disciplines or 
giving them up, finding solutions to encourage the development of practical activities vs. theoretical ones, prohibiting students from logging on to social media or blocking their participation in classes after the start of teaching activities if they do so, and mandatory activation of students' video cameras during activities to avoid distractions. Moreover, teachers should adopt a patient attitude towards students who have jobs, find it harder to connect or do not understand work tasks. It is also suggested that teachers benefit from better IT equipment, give up on written examination forms, use only grid tests, provide a more detailed explanation of the information transmitted in the courses, argue points with practical examples, record all teaching activities on the work platform and ensure free access to viewing/consulting them, etc.

Table 7. Students' proposals for streamlining online teaching activities.

\begin{tabular}{|c|c|c|c|c|c|c|c|}
\hline \multirow{2}{*}{$\begin{array}{l}\text { Nr. } \\
\text { Crt. }\end{array}$} & \multirow{2}{*}{ Proposals/Expressed Opinion } & \multicolumn{2}{|c|}{ Urban/93 } & \multicolumn{2}{|c|}{ Rural/54 } & \multicolumn{2}{|c|}{ Total/147 } \\
\hline & & Nr. & $(\%)$ & Nr. & $(\%)$ & Nr. & $(\%)$ \\
\hline 1 & I have no null proposals/answers & 35 & 37.63 & 20 & 37.03 & 55 & 37.41 \\
\hline 2 & Everything went very well, I want to continue online & 10 & 10.75 & 1 & 1.85 & 11 & 7.48 \\
\hline 3 & More examples and demonstrations/videos & 6 & 6.45 & 5 & 9.25 & 11 & 7.48 \\
\hline 4 & Involvement of all students in discussions & 6 & 6.45 & 4 & 7.40 & 10 & 6.80 \\
\hline 5 & $\begin{array}{l}\text { Solving problems related to the online platform, improving it } \\
\text { with more functions }\end{array}$ & 5 & 5.37 & 3 & 5.55 & 8 & 5.44 \\
\hline 6 & Return to the classic teaching option & 4 & 4.30 & 4 & 7.40 & 8 & 5.44 \\
\hline 7 & Synthesizing/simplifying the material to make it more accessible & 4 & 4.30 & 3 & 5.55 & 7 & 4.76 \\
\hline 8 & Interactive and fun activities related to the topic discussed & 4 & 4.30 & 2 & 3.70 & 6 & 4.08 \\
\hline 9 & A program that allows us more physical encounters & 3 & 3.22 & 2 & 3.70 & 5 & 3.40 \\
\hline 10 & $\begin{array}{c}\text { Shortening the duration of the hours and increasing the breaks } \\
\text { between them }\end{array}$ & 3 & 3.22 & 2 & 3.70 & 5 & 3.40 \\
\hline 11 & Let's have more free discussions & 3 & 3.22 & 1 & 1.85 & 4 & 2.72 \\
\hline 12 & Fewer papers to be conceived and presented & 3 & 3.22 & 1 & 1.85 & 4 & 2.72 \\
\hline 13 & Offering more teaching materials & 3 & 3.22 & 1 & 1.85 & 4 & 2.72 \\
\hline 14 & Better organization of activities & 1 & 1.07 & 3 & 5.55 & 4 & 2.72 \\
\hline 15 & More practice and less theory & 2 & 2.15 & 1 & 1.85 & 3 & 2.04 \\
\hline 16 & Do not allow connection after the start of classes & 2 & 2.15 & 1 & 1.85 & 3 & 2.04 \\
\hline 17 & Registration of activities on the open access platform & 1 & 1.07 & 2 & 3.70 & 3 & 2.04 \\
\hline 18 & Teachers should be more patient with us & 1 & 1.07 & 2 & 3.70 & 3 & 2.04 \\
\hline 19 & More detailed presentation of the courses & 2 & 2.15 & 1 & 1.85 & 3 & 2.04 \\
\hline 20 & All students should have their video cameras activated & 1 & 1.07 & 1 & 1.85 & 2 & 1.36 \\
\hline 21 & Training students to use the work platform & 1 & 1.07 & 1 & 1.85 & 2 & 1.36 \\
\hline 22 & Greater tolerance for those who work & 1 & 1.07 & 1 & 1.85 & 2 & 1.36 \\
\hline 23 & Higher performance IT equipment for teachers & 0 & - & 2 & 3.70 & 2 & 1.36 \\
\hline 24 & Checks/exams based on grid tests only & 0 & - & 1 & 1.85 & 1 & 0.68 \\
\hline 25 & More time for the student to think about the exam & 0 & - & 1 & 1.85 & 1 & 0.68 \\
\hline 26 & Increasing the number of courses/seminars & 1 & 1.07 & 0 & - & 1 & 0.68 \\
\hline 27 & Using graphic tables for sketches, drawings, etc. & 1 & 1.07 & 0 & - & 1 & 0.68 \\
\hline
\end{tabular}




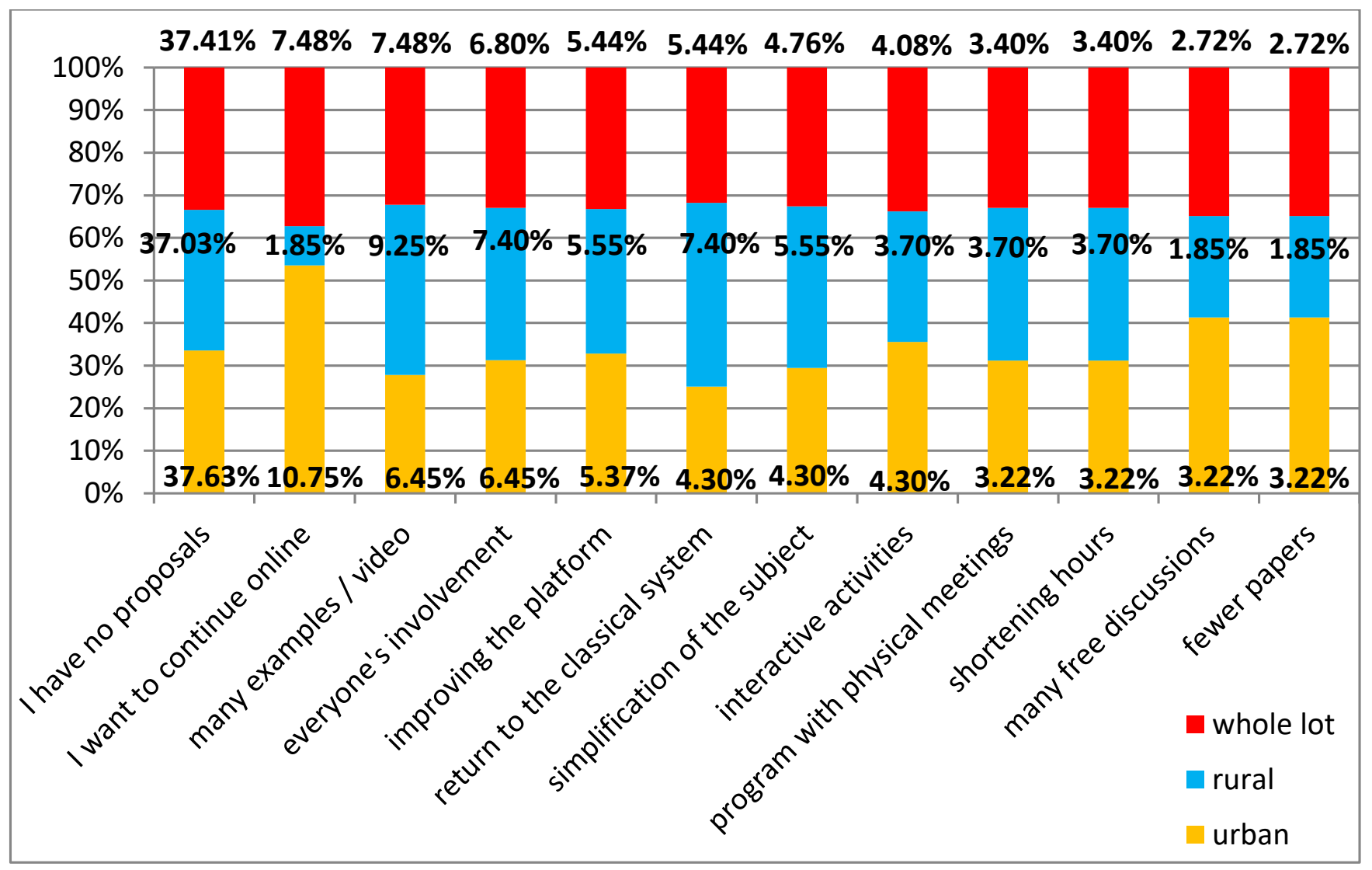

Figure 3. Graphical representation of the main proposals for streamlining online teaching activities.

\section{Discussion}

The analysis of the obtained data confirms the existence of differences of opinion regarding online teaching activities for the three age groups analyzed. It also confirms different scores for free answers, offered by students residing in urban vs. rural areas. This aspect confirms the working hypotheses for a series of items and calls for a differentiated approach to the teaching process. Thus, the issues reported by students must be resolved: boredom, anxiety, fatigue, difficulty concentrating, technical problems, poor involvement of some students, the need for an increased volume of video material for analysis, etc. These can be the starting point for remedying teaching problems and increasing the attractiveness of the online education approach, especially since higher education in physical education and sports has unique features that differentiate it from other specializations.

The results obtained in the present study are largely in line with other research conducted worldwide and which investigated the issue of online activities during the pandemic, noting that they have particular features generated by national specificity, area, socio-economic factors and political climate, but also the specializations of the investigated students (both in terms of reported shortcomings, but also in terms of benefits). Even if the studies carried out exclusively at the level of departments and faculties of physical education and sports are not numerous, there are still various researches related to online education for other specializations, from which analysis can emerge on common and particular aspects of the investigated field.

At national level in Romania, the study conducted by [30] on students of physical education and sports, as well as engineering, at Vasile Alecsandri University of Bacău identifies issues related to socialization and communication, lack of practical activities, limited motivation, poor physical interaction, excessive time spent using IT equipment, sedentary lifestyle and infrastructure problems for students. However, most students 
are satisfied with the measures taken by the university during the pandemic in order to facilitate teaching activities.

The collaboration between teachers, students and administrative staff is important for streamlining online activities for students in Spain, especially for universities that have quickly gone through this process and have no experience. The advantages identified by students refer to the reduction of transport costs and more free time, but it is necessary to reduce the technological gap between the different categories of students [31].

The pandemic has forced higher education institutions to integrate digital technology into teaching; this should not be seen as a definitive solution but rather as a way to improve teaching. A study conducted at the Polytechnic University of Madrid captures an increase in the academic performance of students during the pandemic, which can be explained by the high level of computer skills of teachers and students, good quality IT equipment and knowledge of technology, familiarity with software and good infrastructure [32].

The opinions of Pakistani students on the effectiveness of online teaching are captured by [33]. For them, the proposed option is not as effective as face-to-face learning, signaling socialization problems, difficulties in working in groups for common projects, technical and financial problems related to internet access and lack of interaction with teachers. Some $76 \%$ indicate the increased efficiency of classic vs. online teaching, which is effective only with virus protection. The design and adaptation of the content transmitted to the students and a better digital training of them are necessary, as a premise of the increase in learning efficiency. Prospects for continuing online education after the end of the pandemic in the UAE (United Arab Emirates) are identified by [34]. Only 26\% of students would like to continue only online, and $49 \%$ would prefer a hybrid system (online and classic). The online version must be seriously considered for the future, because $55 \%$ of cases consider this solution to be effective.

The implementation of e-learning in the master's program of the Faculty of Physical Medicine in Malaya between March and June 2020 is seen as positive by 60 students, who are satisfied with video analysis with practical activities and pre-recorded lectures and study flexibility at home. However, the activities and practical experience cannot be replaced, but hybrid study programs will become commonplace. The weak spots refer to internet quality, technical problems, high stress and poor attention and concentration [35].

The advantages and disadvantages of e-learning for students are also presented by [36] after 8 weeks of online teaching activity. They describe the strengths as including studying from the comfort of home, the activities are perceived as pleasant, students have easy access to teaching materials and can follow their own pace of learning. The weaknesses concern technical and connection issues, less student involvement in classes and a lack of physical interaction. There are no significant differences between e-learning and classic schooling in terms of assimilation and level of knowledge, but e-learning is deficient for the formation of specific clinical skills and social interaction, signaling the need for feedback for optimal interaction and effective teaching.

Batez [37] analyzed the relationship between students' IT skills (ICT) and their needs, identifying that they believe they have more ICT skills than they need to handle e-learning (internet, e-mail, file creation and management, communication online, etc.). Out of the group of 360 students investigated, those with high ICT skills and those who frequently use these skills are more satisfied with online activities.

The perceptions and attitudes of 31 students regarding the use of the Zoom application during the pandemic for teaching activities and their comparison with the face-to-face teaching were investigated by Serhan [38]. The main advantage results from the flexibility of the work schedule, and disadvantages are described as the negative effects on motivation and learning experiences, instructors not being familiarized well enough with the platform, technical difficulties and problematic internet access. The research of [39] on 282 students from Bengal (India) reports that the use of online platforms for undergraduate and postgraduate students is accompanied by major issues affecting study, including anxiety and 
depression, unfavorable family climate, poor connection to internet, etc. Most problems are registered by the students from disadvantaged and remote areas.

The streamlining of online teaching activities for medical students is possible by using a mentoring program in which seniors (10 older students, previously trained in a 40-hour program on teaching, learning, communication and consulting skills) used a social networking platform to reduce the stress and anxiety of younger colleagues. Both groups gained, as a unique experience, easier adaptation to new contexts and improved professional skills [40]. Even if the internet provides information that is easy for students to access, teachers have the role of guiding/orienting students in the structured curriculum, according to Thomas et al. [41]. A study conducted on 300 medical students in Mumbai (India) indicated that after 6 months of online activity (posts, lectures, tutorials), students still prefer classical teaching (in person) as a superior option to e-learning. They have computer skills to cope with e-learning tasks, even though $60 \%$ of them did not participate in online programs before the pandemic, but absorption of a doctor's clinical skills still require classical learning.

Online activities are perceived as attractive, interesting and accessible, but cannot compensate for the lack of socialization and physical interaction with teachers and peers. Most of the Greek students surveyed by [42] want to return to the classical teaching system, considering it to be the "normal" option. The 75 Greek students surveyed also identify the elearning option as the only solution to prevent the interruption of academic studies, saying this experience allowing online teaching will occupy a significant share of universities educational offers in the future due to its attractiveness, ease and lower costs, provided that improvements are made to the digital infrastructure. A major role belongs to universities in training teachers in online teaching methods (distance learning).

The psychological impact for students in Italy is highlighted by [43]. The factors that can influence the manifestation of depressive and anxious states include personal health and that of family and friends, as well as uncertainties related to academic progress, with these values being higher than for people working in other fields. A comparative study on depressive states in students in China, Korea and Japan [44] highlighted that Japanese students and women have higher values, but women have higher notions of preventive practice than men, Chinese students are the best at preventive practice, requiring prevention and treatment programs to ensure mental health during the pandemic. The survey of 494 students in Pakistan showed that $41 \%$ have anxiety and $16 \%$ have severe forms, with girls and those with severe forms searching for more social support [45].

The pandemic affected the well-being of $86.8 \%$ of the 787 Australian students investigated by [46], the anxious states being stronger in the case of undergraduate students than in the postgraduate ones, the latter also manifesting a superior state of well-being, so the age level is an important factor in this study. A deterioration of well-being is determined by [47] in $10 \%$ of Swiss students, compared to the stage before the pandemic, manifesting itself in the form of reduced, moderate and severe anxiety, an aspect reinforced by the study of [48] which identifies the psychological suffering, anxiety and depression in Chinese students at Hebei Agricultural University. Spanish students show mild (70.2\%) and severe $(18.7 \%)$ anxiety after a month of pandemic-related restrictions. Women have almost double the values compared to men, the causes being related to poor financial conditions, poor relationships with family, poor quality of sleep and death of relatives [49]. UK students showed a decrease in well-being and physical activity after 9 months of pandemic, and an increase in stress levels and sedentary lifestyle [50]. The investigations of [51] identify pandemic problems in Norwegian physical education. The need for $60 \mathrm{~min}$ of physical activity every school day is indicated. There are different approaches of schools to the discipline of physical education, and the responses of the parents investigated indicate a greater involvement in effort (at home) of younger students. Physical activities are often initiated by parents themselves. However, most of those surveyed are concerned about the sedentary behavior of children, as average values show a reduction in participation in physical activity, compared to the pre-pandemic period. 
In accordance with the previously analyzed study, it would be advisable to start research at a national level. The aim would be to quantify the effects of the pandemic on the quality of teaching and changing the lifestyle of pupils and students, especially on the part of physical activism. Even if most of the analyzed sources highlight the shortcomings of the online teaching system, it should be noted that the opinions of the investigated students also identify favorable aspects. Thus, the e-learning activity facilitated the continuity of the didactic act. We consider that this precedent has already been created and that online activities will have an important and viable share in the future of teaching in the university environment of physical education and sports, even if the practical disciplines require atypical solutions to achieve the proposed objectives. Other research directions could capture the effects of online activities on improving the computer skills of students and teachers, but also changes related to the motor behavior of the young generation, with involvement in other variants of physical activities (other than classic sports games), which do not involve large groups. Last but not least, the consultation of the types of physical activities exemplified on YouTube, with new structures, sports materials and training plans for different sports disciplines (carried out by most pandemic teachers), contributed to changing the teaching optics and improving the level of knowledge, demonstrating that there are viable and diversified alternatives to the classical teaching system.

\section{Conclusions}

The study undertaken is a good way to assess the attitudes of FEFS students towards the online teaching process, which has specific features compared to other specializations of the university environment, needing a harmonious combination of theoretical activities and those addressing practical skills. The multivariate (at the level of questionnaire factors) and univariate (at the level of each feature measured by the respective item) analyses show that the age of students is an independent variable that generates different scores and, in some situations, is statistically significant for independent variables, represented by the average values of responses to the questions from the questionnaire. The values of $\mathrm{F}$ are associated with significant thresholds for a number of measured traits: boredom generated by activities, perceived stress level, participation and adaptation to activities, motivation and involvement in lessons, usefulness of online teaching and quality of teaching, estimating the level of professional training through online activities and the existence of other concerns that disrupt online concentration. For these dependent variables, the comparison between the three age ranges indicates average scores that differ significantly for the group of students over 30 years, compared to the group under 20 and 20-30 years old, so there is an obvious contrast in the attitude of this age group towards the online teaching process compared to the other two groups, so the optics and needs of students regarding teaching vary depending on their age. Identifying these features is important for effective communication and a differentiated adaptation of teaching in line with the requirements of the students.

Centralizing the free answers also provides a true picture of strengths, existing problems and proposed solutions. The advantages include the increase in free time, the accessibility and the comfort of home, the reduction of costs, other activities carried out in parallel, the protection for COVID-19, the personal pace of learning, etc. The reported deficiencies concern technical and internet connection problems, poor attention during lessons, difficulty in understanding the subject, lack of physical interaction and socialization, excess of theoretical activities and lack of practical ones. The proposals are very heterogeneous and contradictory in some cases. They include continuing online teaching, a rapid return to the classical system, priority use of demonstrations and videos, involvement of all the students in discussions, simplification of the taught subject and focus on interactive activities, improving access to the work platform and improving the facilities offered by it, etc. All these opinions expressed, combined with the experience gained by the teachers, can represent solid premises for streamlining teaching activities in the following academic 
years if the problems generated by the pandemic require it, or if online mechanisms gain ground and dominate future teaching activities.

\section{Limits of the Study}

The research conducted is not exhaustive. There are premises for continuing and optimizing studies related to the adaptation of students to the requirements of online activities. Its limits are related to the relatively small number of subjects and their unilateral specialization, physical education and sports, but especially due to the fact that no opinions were collected from students in the next levels of education (master's and doctorate) within the institution, for whom the experiences and relationship with theoretical and practical activities are different. A complementary understanding of the characteristics and limitations of e-learningwould be the questioning of the teachers involved, which would generate a more accurate picture of this process, highlighting the contradictions and similar issues related to the views of the two groups involved-teachers and students. Last but not least, the application of the questionnaire for other specializations within the university center or for other universities at national and international levels allows the identification of common features and particular differences/aspects of the online teaching process, allowing most syncopes to be eliminated in the future and thus transfer the verified solutions to increase the quality of teaching in the COVID-19 pandemic.

Author Contributions: Conceptualization, G.D.M. and G.M.; methodology, G.D.M. and D.A.I.; software, G.D.M. and I.S. and G.M.; formal analysis, D.A.I.; investigation G.D.M. and G.M.; resources, G.D.M. and D.A.I.; data curation G.D.M. and I.S.; writing-original draft preparation, G.D.M.; writing-review and editing, I.S. and M.O.A.M.; visualization, G.D.M. and G.M.; supervision, I.S. and M.O.A.M.; project administration, G.D.M. and G.M.; funding acquisition, D.A.I. All authors have read and agreed to the published version of the manuscript.

Funding: The work of Daniel Andrei IORDAN was supported by the project "ANTREPRENORDOC", Contract no. 36355/23.05.2019, financed by The Human Capital Operational Program 2014e2020 (POCU), Romania.

Institutional Review Board Statement: Institutional approval for studies involving humans was acquired.

Informed Consent Statement: Consent was obtained from all subjects involved in the study.

Conflicts of Interest: The authors declare no conflict of interest.

\section{References}

1. Rapanta, C.; Botturi, L.; Goodyear, P.; Guàrdia, L.; Koole, M. Online University Teaching During and After the COVID-19 Crisis: Refocusing Teacher Presence and Learning Activity. Postdigital Sci. Educ. 2020, 2, 923-945. [CrossRef]

2. Tukan, F.M.E. Challenges and Strategies Using Application in Online Teaching during Pandemic. Engl. Educ. Engl. J. Teach. Learn. 2020, 8, 138-154. [CrossRef]

3. Bao, W. COVID-19 and Online Teaching in Higher Education: A Case Study of Peking University. Hum. Behav. Emerg. Technol. 2020, 2, 113-115. [CrossRef] [PubMed]

4. Potra, S.; Pugna, A.; Pop, M.-D.; Negrea, R.; Dungan, L. Facing COVID-19 Challenges: 1st-Year Students' Experience with the Romanian Hybrid Higher Educational System. Int. J. Environ. Res. Public Health 2021, 18, 3058. [CrossRef] [PubMed]

5. Mishra, L.; Gupta, T.; Shree, A. Online Teaching-Learning in Higher Education during Lockdown Period of COVID-19 Pandemic. Int. J. Educ. Res. Open 2020, 1, 100012. [CrossRef]

6. Aperribai, L.; Cortabarria, L.; Aguirre, T.; Verche, E.; Borges, Á. Teacher's Physical Activity and Mental Health during Lockdown due to the COVID-2019 Pandemic. Front. Psychol. 2020, 11, 577886. [CrossRef] [PubMed]

7. Joshi, A.; Vinay, M.; Bhaskar, P. Impact of Coronavirus Pandemic on the Indian Education Sector: Perspectives of Teachers on Online Teaching and Assessments. Interact. Technol. Smart Educ. 2020. ahead-of-print. [CrossRef]

8. Hebebci, M.T.; Bertiz, Y.; Alan, S. Investigation of Views of Students and Teachers on Distance Education Practices during the Coronavirus (COVID-19) Pandemic. IJTES 2020, 4, 267-282. [CrossRef]

9. Tan, H.R.; Chng, W.H.; Chonardo, C.; Ng, M.T.T.; Fung, F.M. How Chemists Achieve Active Learning Online during the COVID-19 Pandemic: Using the Community of Inquiry (CoI) Framework to Support Remote Teaching. J. Chem. Educ. 2020, 97, 2512-2518. [CrossRef] 
10. Owusu-Fordjour, C.; Koomson, C.K.; Hanson, D. The impact of COVID-19 on learning-The perspective of the ghanaian student. Eur. J. Educ. Stud. 2020, 7, 88-100. [CrossRef]

11. Barkley, J.E.; Lepp, A.; Glickman, E.; Farnell, G.; Beiting, J.; Wiet, R.; Dowdell, B. The Acute Effects of the COVID-19 Pandemic on Physical Activity and Sedentary Behavior in University Students and Employees. Int. J. Exerc. Sci. 2020, 13, $1326-1339$.

12. López-Valenciano, A.; Suárez-Iglesias, D.; Sanchez-Lastra, M.A.; Ayán, C. Impact of COVID-19 Pandemic on University Students' Physical Activity Levels: An Early Systematic Review. Front. Psychol. 2021, 11, 624567. [CrossRef]

13. Meza, E.I.A.; López, J.A.H. Physical Activity in University Student Athletes, Prior and in Confinement due to Pandemic Associated with COVID-19. Retos Nuevas Tend. En Educ. Física Deporte Y Recreación 2021, 39, 572-575.

14. Rodríguez-Larrad, A.; Mañas, A.; Labayen, I.; González-Gross, M.; Espin, A.; Aznar, S.; Serrano-Sánchez, J.A.; Vera-Garcia, F.J.; González-Lamuño, D.; Ara, I.; et al. Impact of COVID-19 Confinement on Physical Activity and Sedentary Behaviour in Spanish University Students: Role of Gender. Int. J. Environ. Res. Public Health 2021, 18, 369. [CrossRef] [PubMed]

15. Wickersham, A.; Carr, E.; Hunt, R.; Davis, J.P.; Hotopf, M.; Fear, N.T.; Downs, J.; Leightley, D. Changes in Physical Activity among United Kingdom University Students Following the Implementation of Coronavirus Lockdown Measures. Int. J. Environ. Res. Public Health 2021, 18, 2792. [CrossRef] [PubMed]

16. Varea, V.; González-Calvo, G. Touchless Classes and Absent Bodies: Teaching Physical Education in Times of Covid-19. Sport Educ. Soc. 2020, 1-15. [CrossRef]

17. Zhu, X.; Wang, H. Implementation and Consideration of Online Teaching of Physical Education Courses in Chinese Universities under the COVID-19 Pandemic; Atlantis Press: Zhengzhou, China, 2020; pp. 111-115.

18. Berg-Beckhoff, G.; Dalgaard Guldager, J.; Tanggaard Andersen, P.; Stock, C.; Smith Jervelund, S. What Predicts Adherence to Governmental COVID-19 Measures among Danish Students? Int. J. Environ. Res. Public Health 2021, 18, 1822. [CrossRef] [PubMed]

19. Brancaccio, M.; Mennitti, C.; Gentile, A.; Correale, L.; Buzzachera, C.F.; Ferraris, C.; Montomoli, C.; Frisso, G.; Borrelli, P.; Scudiero, O. Effects of the COVID-19 Pandemic on Job Activity, Dietary Behaviours and Physical Activity Habits of University Population of Naples, Federico II-Italy. Int. J. Environ. Res. Public Health 2021, 18, 1502. [CrossRef] [PubMed]

20. Busse, H.; Buck, C.; Stock, C.; Zeeb, H.; Pischke, C.R.; Fialho, P.M.M.; Wendt, C.; Helmer, S.M. Engagement in Health Risk Behaviours before and during the COVID-19 Pandemic in German University Students: Results of a Cross-Sectional Study. Int. J. Environ. Res. Public Health 2021, 18, 1410. [CrossRef] [PubMed]

21. Volken, T.; Zysset, A.; Amendola, S.; Klein Swormink, A.; Huber, M.; von Wyl, A.; Dratva, J. Depressive Symptoms in Swiss University Students during the COVID-19 Pandemic and Their Correlates. Int. J. Environ. Res. Public Health 2021, 18, 1458. [CrossRef]

22. Opariuc-Dan, C. Statistică Aplicată În Științele Socio-Umane. Analiza Asocierilor Și a Diferențelor Statistice; Arhip-Art Sibiu: Constanța, Romania, 2011.

23. Sarma, K.V.S.; Vardhan, R.V. Multivariate Statistics Made Simple: A Practical Approach; CRC Press: Boca Raton, FL, USA, 2018; ISBN 978-0-429-87787-2.

24. Grice, J.W.; Iwasaki, M. A Truly Multivariate Approach to MANOVA. Appl. Multivar. Res. 2008, 12, 199-226. [CrossRef]

25. O'Brien, R.G.; Kaiser, M.K. MANOVA Method for Analyzing Repeated Measures Designs: An Extensive Primer. Psychol. Bull. 1985, 97, 316-333. [CrossRef]

26. Weerahandi, S. Generalized Inference in Repeated Measures: Exact Methods in MANOVA and Mixed Models; John Wiley \& Sons: Hoboken, NJ, USA, 2004; ISBN 978-0-471-47017-5.

27. Armstrong, R.A. When to Use the Bonferroni Correction. Ophthalmic Physiol. Opt. 2014, 34, 502-508. [CrossRef] [PubMed]

28. Murariu, G. Fizică Statistică Și Computațională-Aspecte Contemporane si Aplicații; Galați University Press: Galati, Romania, 2018.

29. Murariu, G.; Munteanu, D. Lucrări Practice de Identificare, Modelare Şi Simulare a Proceselor Fizice; Galați University Press: Galati, Romania, 2018.

30. Radu, M.-C.; Schnakovszky, C.; Herghelegiu, E.; Ciubotariu, V.-A.; Cristea, I. The Impact of the COVID-19 Pandemic on the Quality of Educational Process: A Student Survey. Int. J. Environ. Res. Public Health 2020, 17, 7770. [CrossRef] [PubMed]

31. Ramírez-Hurtado, J.M.; Hernández-Díaz, A.G.; López-Sánchez, A.D.; Pérez-León, V.E. Measuring Online Teaching Service Quality in Higher Education in the COVID-19 Environment. Int. J. Environ. Res. Public Health 2021, 18, 2403. [CrossRef] [PubMed]

32. Iglesias-Pradas, S.; Hernández-García, Á.; Chaparro-Peláez, J.; Prieto, J.L. Emergency Remote Teaching and Students' Academic Performance in Higher Education during the COVID-19 Pandemic: A Case Study. Comput. Hum. Behav. 2021, 119, 106713. [CrossRef]

33. Adnan, M.; Anwar, K. Online Learning amid the COVID-19 Pandemic: Students' Perspectives. Online Submiss. 2020, 2, 45-51. [CrossRef]

34. Almuraqab, N.A.S. Shall Universities at the UAE Continue Distance Learning after the COVID-19 Pandemic? In Revealing Students' Perspective; Social Science Research Network: Rochester, NY, USA, 2020.

35. Azlan, C.A.; Wong, J.H.D.; Tan, L.K.; Huri, M.S.N.; Ung, N.M.; Pallath, V.; Tan, C.P.L.; Yeong, C.H.; Ng, K.H. Teaching and Learning of Postgraduate Medical Physics Using Internet-Based e-Learning during the COVID-19 Pandemic-A Case Study from Malaysia. Phys. Med. 2020, 80, 10-16. [CrossRef]

36. Bączek, M.; Zagańczyk-Bączek, M.; Szpringer, M.; Jaroszyński, A.; Wożakowska-Kapłon, B. Students' Perception of Online Learning during the COVID-19 Pandemic. Medicine 2021, 100, e24821. [CrossRef] 
37. Batez, M. ICT Skills of University Students from the Faculty of Sport and Physical Education during the COVID-19 Pandemic. Sustainability 2021, 13, 1711. [CrossRef]

38. Serhan, D. Transitioning from Face-to-Face to Remote Learning: Students' Attitudes and Perceptions of Using Zoom during COVID-19 Pandemic. Int. J. Technol. Educ. Sci. 2020, 4, 335-342. [CrossRef]

39. Kapasia, N.; Paul, P.; Roy, A.; Saha, J.; Zaveri, A.; Mallick, R.; Barman, B.; Das, P.; Chouhan, P. Impact of Lockdown on Learning Status of Undergraduate and Postgraduate Students during COVID-19 Pandemic in West Bengal, India. Child. Youth Serv. Rev. 2020, 116, 105194. [CrossRef]

40. Kazerooni, A.R.; Amini, M.; Tabari, P.; Moosavi, M. Peer Mentoring for Medical Students during the COVID-19 Pandemic via a Social Media Platform. Med. Educ. 2020, 54, 762-763. [CrossRef] [PubMed]

41. Thomas, N.S.; Thakkar, M.; Ghanekar, J. Student's Perception on Online Teaching, Learning and Evaluation during the Covid-19 Pandemic: A Survey. Int. J. Health Clin. Res. 2021, 4, 61-67.

42. Kedraka, K.; Kaltsidis, C. Effects of the Covid-19 Pandemic on University Pedagogy: Students' Experiences and Considerations. Eur. J. Educ. Stud. 2020, 7, 17-29. [CrossRef]

43. Romeo, A.; Benfante, A.; Castelli, L.; Di Tella, M. Psychological Distress among Italian University Students Compared to General Workers during the COVID-19 Pandemic. Int. J. Environ. Res. Public Health 2021, 18, 2503. [CrossRef] [PubMed]

44. Zhao, B.; Kong, F.; Aung, M.N.; Yuasa, M.; Nam, E.W. Novel Coronavirus (COVID-19) Knowledge, Precaution Practice, and Associated Depression Symptoms among University Students in Korea, China, and Japan. Int. J. Environ. Res. Public Health 2020, 17, 6671. [CrossRef] [PubMed]

45. Baloch, G.M.; Kamaludin, K.; Chinna, K.; Sundarasen, S.; Nurunnabi, M.; Khoshaim, H.B.; Hossain, S.F.A.; Sukayt, A.A.; Baloch, L.G. Coping with COVID-19: The Strategies Adapted by Pakistani Students to Overcome Implications. Int. J. Environ. Res. Public Health 2021, 18, 1799. [CrossRef]

46. Dodd, R.H.; Dadaczynski, K.; Okan, O.; McCaffery, K.J.; Pickles, K. Psychological Wellbeing and Academic Experience of University Students in Australia during COVID-19. Int. J. Environ. Res. Public Health 2021, 18, 866. [CrossRef] [PubMed]

47. Dratva, J.; Zysset, A.; Schlatter, N.; von Wyl, A.; Huber, M.; Volken, T. Swiss University Students' Risk Perception and General Anxiety during the COVID-19 Pandemic. Int. J. Environ. Res. Public Health 2020, 17, 7433. [CrossRef] [PubMed]

48. Li, H.Y.; Cao, H.; Leung, D.Y.P.; Mak, Y.W. The Psychological Impacts of a COVID-19 Outbreak on College Students in China: A Longitudinal Study. Int. J. Environ. Res. Public Health 2020, 17, 3933. [CrossRef] [PubMed]

49. Garvey, A.M.; Jimeno García, I.; Otal Franco, S.H.; Mir Fernández, C. The Psychological Impact of Strict and Prolonged Confinement on Business Students during the COVID-19 Pandemic at a Spanish University. Int. J. Environ. Res. Public Health 2021, 18, 1710. [CrossRef]

50. Savage, M.J.; Hennis, P.J.; Magistro, D.; Donaldson, J.; Healy, L.C.; James, R.M. Nine Months into the COVID-19 Pandemic: A Longitudinal Study Showing Mental Health and Movement Behaviours Are Impaired in UK Students. Int. J. Environ. Res. Public Health 2021, 18, 2930. [CrossRef] [PubMed]

51. Roe, A.; Blikstad-Balas, M.; Dalland, C.P. The Impact of COVID-19 and Homeschooling on Students' Engagement With Physical Activity. Front. Sports Act. Living 2021, 2, 589227. [CrossRef] [PubMed] 